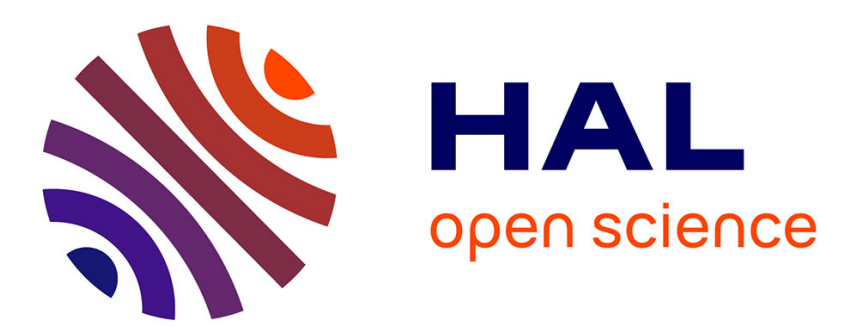

\title{
Effect of a caloric restriction regimen on the angiogenic capacity of aorta and on the expression of endothelin-1 during ageing
}

Floriana Facchetti, Elena Monzani, Gabriella Cavallini, Ettore Bergamini, Caterina Am La Porta

\section{To cite this version:}

Floriana Facchetti, Elena Monzani, Gabriella Cavallini, Ettore Bergamini, Caterina Am La Porta. Effect of a caloric restriction regimen on the angiogenic capacity of aorta and on the expression of endothelin-1 during ageing. Experimental Gerontology, 2007, 42 (7), pp.662. 10.1016/j.exger.2007.04.001 . hal-00499011

\section{HAL Id: hal-00499011 https://hal.science/hal-00499011}

Submitted on 9 Jul 2010

HAL is a multi-disciplinary open access archive for the deposit and dissemination of scientific research documents, whether they are published or not. The documents may come from teaching and research institutions in France or abroad, or from public or private research centers.
L'archive ouverte pluridisciplinaire HAL, est destinée au dépôt et à la diffusion de documents scientifiques de niveau recherche, publiés ou non, émanant des établissements d'enseignement et de recherche français ou étrangers, des laboratoires publics ou privés. 


\section{Accepted Manuscript}

Effect of a caloric restriction regimen on the angiogenic capacity of aorta and on the expression of endothelin-1 during ageing

Floriana Facchetti, Elena Monzani, Gabriella Cavallini, Ettore Bergamini, Caterina AM La Porta

PII:

$$
\text { S0531-5565(07)00081-2 }
$$

DOI: 10.1016/j.exger.2007.04.001

Reference:

$$
\text { EXG } 8328
$$

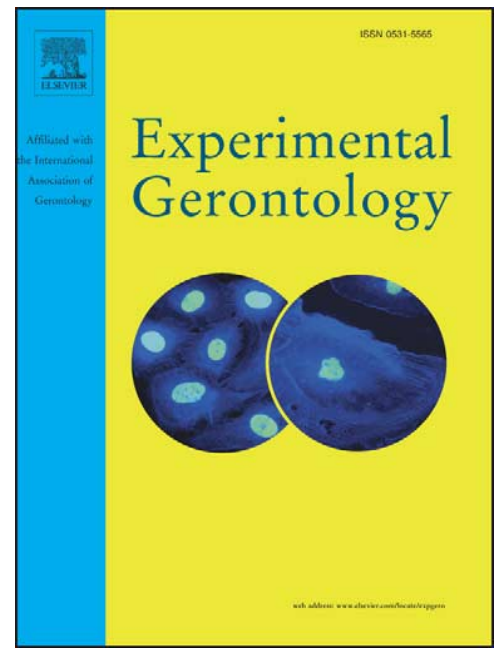

To appear in:

Experimental Gerontology

Received Date:

15 November 2006

Revised Date:

16 March 2007

Accepted Date:

3 April 2007

Please cite this article as: Facchetti, F., Monzani, E., Cavallini, G., Bergamini, E., La Porta, C.A., Effect of a caloric restriction regimen on the angiogenic capacity of aorta and on the expression of endothelin-1 during ageing, Experimental Gerontology (2007), doi: 10.1016/j.exger.2007.04.001

This is a PDF file of an unedited manuscript that has been accepted for publication. As a service to our customers we are providing this early version of the manuscript. The manuscript will undergo copyediting, typesetting, and review of the resulting proof before it is published in its final form. Please note that during the production process errors may be discovered which could affect the content, and all legal disclaimers that apply to the journal pertain. 


\title{
EFFECT OF A CALORIC RESTRICTION REGIMEN ON THE ANGIOGENIC CAPACITY OF AORTA AND ON THE EXPRESSION OF ENDOTHELIN-1 DURING AGEING.
}

\author{
Floriana Facchetti ${ }^{1}$, Elena Monzani ${ }^{1}$, Gabriella Cavallini ${ }^{2}$, Ettore Bergamini ${ }^{2}$, \\ Caterina AM La Porta ${ }^{1}$
}

\begin{abstract}
Department of Biomolecular Science and Biotechnology, University of Milan, Italy ${ }^{1}$; Centro di Ricerca di Biologia e Patologia dell'Invecchiamento, University of Pisa, Italy ${ }^{2}$
\end{abstract}




\begin{abstract}
Ageing is accompanied by impaired angiogenesis, as well as by a deficient expression of several angiogenic growth factors and the alteration of endothelial functions. Caloric restriction (CR) is the only intervention that can extend lifespan and retard age-related-decline functions in mammals by reducing the rate of ageing and the progression of the associated diseases. Herein, we have investigated the effects of ageing and of a caloric restriction regimen (mild or severe) on the angiogenic response and on the expression of endothelin-1 (ET-1) in the aorta of male 3-, 12- or 24-month-old Sprague Dawley rats fed ad libitum (AL), fed ad libitum and fasted 1 day a week (mild CR) or fasted every other in alternate days (severe CR).

Our findings, using the rat aorta ring assay, show that the angiogenic capacity of aorta decreases with ageing in the oldest rats only. Furthermore, caloric restriction counteracts the age-related changes caloric restrictions actually give raise to a similar recovery. Interestingly, the mRNA ET-1 levels as well as ET-1 expression in aorta sprouting decreases both in middle and in aged animals. Mild and severe caloric restriction regimens prevents ET-1 changes.
\end{abstract}




\section{Introduction}

Angiogenesis, that is the formation of new vessels from existing vasculature, is a complex process that includes activation, migration, and proliferation of endothelium. The neovascular process is regulated by a wide range of locally released or circulating soluble mediators (D'Amore and Thompson, 1987).

Aging is associated with a progressive deterioration of physiological function that impairs the ability of an organism to maintain homeostasis and, consequently, increases the organism's susceptibility to disease and death (Harman, 2001). Angiogenesis is both delayed and altered with age (Rivard et al., 1999). Diseases such as diabetes, atherosclerosis and cancer can affect vascular function (Williams, 1998; Edelberg and Reed, 2003). In this connection, animal models offer identical genetic backgrounds, controlled environmental exposures and thus a suitable way to define the role of ageing in vascular impairment (Edelberg and Reed, 2003).

Caloric restriction (CR) is an important model to investigate mechanisms of biological ageing. Researches spanning for more than 70 years have shown that a $40 \%$ caloric restriction consistently extends the median and maximum lifespan and health span in rodents and perhaps in primates and humans (Roth, 1999; Masoro, 2002; Mattinson et al., 2003) and may counteract age related changes in tissue function (Payne et al., 2003). A milder (10\%) regimen of food restriction had significant beneficial effects on animal's longevity, decreased the incidence of neoplastic and non-neoplastic lesions, counteracted the aging-related changes in cell maintenance (autophagy) and biomarker accumulation (dolichol) (Duffy et al., 2004a,b; Parentini et al., 2005). Publications on the effects of a 40\% severe CR regimen on angiogenesis are conflicting: CR was reported to increase microvascular density and cerebral blood flow in aged rats (Lynch et al., 1999); to reduce vascular density in peritumoral (but not intratumoral) tissue (Thompson et al., 2004); to have significant anti-angiogenic effects in three distinct brain tumor models (Mukherjee et al., 2004). The effects of milder CR regimens on angiogenesis were not explored.

In the present study we have tested the effects of mild and severe CR regimens on age-related decline in the angiogenic capacity of rat aorta using an ex vivo model (Nicosia et al., 1994) that approximates many of the physiologic aorta properties (Nicosia et al., 1994) and it is suitable to quantify spontaneous aorta angiogenesis (Blacher et al., 2001). We also focused on a factor playing a pivotal role on the physiological aorta functions such as endothelin-1 (ET-1) (Marasciulo et al., 2006). ET-1 is in fact the most abundant isoform of a family of small, structurally-related, vasoactive peptides 
which is produced by vascular endothelial cells (Yanagisawa et al., 1988),

Taken together our data show that the angiogenic capacity of aorta using an ex-vivo model as well as ET-1 levels were significantly reduced in the aorta of 12 and 24 months old rats in comparison to 3.5 months old rats. Furthermore, mild or severe caloric restriction (CR) treatments recover such a capability modulating ET-1 levels in aged animals. 


\section{Materials and methods}

\subsection{Animals}

Male rats of the Sprague-Dawley strain were divided into three groups, 3.5, 12 and 24 month old respectively, which were maintained (a) on standard laboratory food (Teklad, Harlan Italy, S. Pietro in Natisone, Italy) ad libitum (AL); (b) fed ad libitum and fasted 1 day a week (FW); (c) on an every other day (EOD) ad libitum feeding regimen. All rats had free access to water. Food was withdrawn $16 \mathrm{~h}$ before experimentation. Rats on the EOD restricted diet were sacrificed on the day of fasting. At the given age, rats were anaesthetized by the intraperitoneal injection of pentobarbital (50 $\mathrm{mg} / \mathrm{kg}$ body weight) and aorta was quickly excised. In Table 1 is reported the body weight, the food consumption and the survival of young and aged rats $(3.5,612,18$ and 24-month old rats) submitted to AL, FW or EOD regimen.

\subsection{Rat aorta ring assay}

Angiogenesis was studied by culturing aortic explants in three-dimensional matrix gels according to a previous paper (Nicosia and Ottinetti, 1990). Thoracic aortas were removed and immediately transferred to a culture dish containing cold serum-free Dulbecco modified Eagle medium (DMEM, Sigma Aldrich). The periaortic fibroadipose tissue was carefully removed with fine microdissecting forceps and iridectomy scissors paying special attention not to damage the aortic wall. Aortic rings were obtained by cross-sectioning at $1 \mathrm{~mm}$ intervals the thoracic aorta (approximately 15 per aorta) and extensively rinsed in 5 consecutive washes of DMEM. The proximal and distal $1 \mathrm{~mm}$ of the aorta, which were used to hold the explants with the forceps during the dissection, were discarded. Before embedding the aortic rings in collagen gel, the bottom of each well was coated with $40 \mu$ of collagen solution $(2 \mathrm{mg} / \mathrm{ml}$ collagen stock solution extract from tail of rat). The rings were than placed individually on the bottom of $1.2 \mathrm{~cm}^{2}$ wells (8-well NUNC dishes) with the luminal axis of each ring lying parallel to the bottom of the culture dish. After the collagen solution was allowed to gel for $5 \mathrm{~min}$ at $37^{\circ} \mathrm{C}, 0.3 \mathrm{ml}$ serum-free Endothelial Cell Basal Medium (Clonetics) was added to each culture. The aortic ring/collagen gel preparations were kept in a humidified $\mathrm{CO}_{2}$ incubator at $37{ }^{\circ} \mathrm{C}$. The medium was changed three times a week starting from day 3. The angiogenic response of aortic cultures was measured in the live cultures by counting the number of neovessels over time. The following criteria were used for counting microvessels: (a) microvascular sprouts were distinguished from fibroblasts 
based on their unique morphology; (b) one sprouts generated two new sprouts; (c) each loop was counted as two sprouts since it was usually formed by a process of anastomosis between two converging microvessels.

Collagen was prepared as here described: isolated rat tail tendons was dissolved in $0.5 \mathrm{M}$ acetic acid, shacked for $48 \mathrm{~h}$ at $4{ }^{\circ} \mathrm{C}$, dialyzed in $0.1 \mathrm{X}$ DMEM (pH 4.0), and stored at $4{ }^{\circ} \mathrm{C}$. The final collagen solution was prepared by mixing on ice 8 volumes of $2 \mathrm{mg} / \mathrm{ml}$ collagen, 1 volume of $23.4 \mathrm{mg} / \mathrm{ml}$ sodium bicarbonate, and 1 volume of 10X DMEM.

\subsection{RT-PCR analysis}

Total RNA was extracted from aorta using the Rneasy Mini Kit (Qiagen) according to specialized protocol for tissue rich of contractile proteins, connective tissue and collagen. The RNA concentration was determined spectrophotometrically at 260nm. Total RNA (1-5 $\mu \mathrm{g})$ was reverse transcribed into complementary DNA (cDNA) using eAMV-RT Kit (Sigma); PCR reactions were performed in $50 \mu \mathrm{l}$ using $200 \mu \mathrm{M}$ dNTPs (Sigma), $1.5 \mathrm{U}$ of RED-Taq polymerase (Sigma), 1X RED buffer (Sigma), $0.3 \mu \mathrm{M}$ of specific oligonucleotide primers, and $2 \mu \mathrm{l}$ of cDNA was amplified. The sequence of the primers, the lengths of PCR products and the annealing temperatures are listed in Table 2. After an initial denaturation at $95^{\circ} \mathrm{C}$ for 15 minutes, PCR was for 40 cycles with denaturation at $95^{\circ} \mathrm{C}$ for 30 seconds, annealing at the appropriate temperature for 15 seconds, and extension at $72^{\circ} \mathrm{C}$ for 30 seconds. Following the final cycle of amplification, 10 -minutes incubation at $72^{\circ} \mathrm{C}$ was performed to ensure that all products were full length. Ten microliters of the RT-PCR products were electrophoresed on $1.5 \%$ agarose gels, stained with ethidium bromide, visualized with an ultraviolet transilluminator, and photographed. The expression of beta-actin mRNA was used as housekeeping gene. Finally, to check the amplification of the correct band, all the bands were purified and sequenced.

\subsection{Immunohistochemistry}

Rat aorta were fixed in $10 \%$ neutral buffered formalin for $72 \mathrm{~h}$ and then embedded in paraffin. Consecutive four-micrometer sections were analysed by immunohistochemistry. Briefly, sections were deparaffinized in xylene, rehydrated through graded concentrations of ethanol, and then incubated with hydrogen peroxide to block endogenous peroxidase activity and finally washed in Tris-buffered saline solution. Then, they were heated for $5 \mathrm{~min}$ in citrate buffer $\mathrm{pH} 6.0$ (microwaves $700 \mathrm{~W}$ ) and incubated for $18 \mathrm{~h}$ at $4{ }^{\circ} \mathrm{C}$ with the primary antibody mouse anti- rat ET-1 (1:200, Affinity Bioreagent). Negative controls were obtained omitting the primary antibody. Sections were then incubated with a biotinylated 
anti-mouse secondary antibody (Vector) for 30min at room temperature. Reactions were developed using DAB as chromogene and counterstained with Mayer' hematoxylin. All experimental and control slides were prepared in parallel to avoid technical variability.

\subsection{Statistical analysis}

The ANOVA one-way test was used to determine statistical significance. For all statistical analyses the level of significance was set at $\mathrm{p}<0.05$.

\begin{tabular}{|l|l|l|l|}
\hline GENE & PRIMERS & $\begin{array}{l}\text { FRAGMENT } \\
\text { SIZE bp }\end{array}$ & $\begin{array}{l}\text { TEMPERATURE OF } \\
\text { ANNEALING (Celsius } \\
\text { degree) }\end{array}$ \\
\hline$\beta$-ACTIN & $\begin{array}{l}\text { Sense 5'-TCCTAGCACCATGAAGATC } \\
\text { Antisense 5'-AAACGCAGCTCAGTAACAG }\end{array}$ & 190 & 47 \\
\hline ET-1 & $\begin{array}{l}\text { Sense 5' - TTGCTCCTGCTCCTCCTTGAT } \\
\text { Antisense 5'-TAGACCTAGAAGGGCTTCCTAGT }\end{array}$ & 119 & 60 \\
\hline
\end{tabular}

Table 2: primer sequences, cDNA fragment lengths and annealing temperatures used for RT-PCR (for ET-1: Iemitsu et al, 2002). 


\section{Results}

Figure 1 (panel A) shows that the capacity of angiogenesis decreased in 24 months old rats (90\%, p<0.001 vs 3.5months-old rats), but was not modified in 12 months old rats with respect to young ones (Fig.1, A). Panel B of the same figure shows that both EOD and FW feeding enhanced angiogenic capacity in aged animals $(45 \%, \mathrm{p}<0.05$ and $63 \%, \mathrm{p}<0.05$ vs untreated animals for EOD and FW, respectively), and caused partial recovery.

Furthermore, Table 3 shows that ET-1 levels in rat aorta decreased significantly both in 12month $(-29 \%)$ and 24-month $(-41 \%)$ aged animals with respect to young once $(\mathrm{p}<0.001)$. In contrast, both mild and severe caloric restriction fully prevented the decline in ET-1 aorta mRNA expression in middle and aged animals (Table 3). Accordingly, immunohystochemistry analysis confirmed a decreased level of expression of ET-1 in aged animals (12-month old animals data not shown) with respect to 3-month old rats (Fig.2, panel A). The caloric restriction regimen prevented, in addition, such a decrease (Fig. 2, panel B). On the other hand, no specific correlation between vessel aorta sprouts and ET-1 expression was observed in young animals. 


\section{Discussion}

\section{Effect of ageing and caloric restriction regimen on rat aorta sprout capacity}

The process of angiogenesis, during which new blood vessels are formed, is impaired during ageing (Edelberg and Reed, 2003). Ageing is a universal process affecting most cells, and concurrent studies in vitro have confirmed that the age-related delay in angiogenesis is associated with several deficits in cell functions. The latter include slowed migration of aged microvascular endothelial cells (Reed et al., 2000) and fibroblasts (Reed et al., 2001; Mogford et al., 2002); lower nitric oxide (NO) production and increased sensitivity of endothelial cells to apoptotic stimuli (Vasa et al., 2000; Hoffmann et al., 2001; Chavakis and Dimmeler, 2002); a defective response in aged cells to the mitogenic effects of vascular endothelium growth factor (VEGF) (Rivard et al. 1999) and the antiproliferative effects of transforming growth factor (TGF)- $\beta 1$ (McCaffrey and Falcone, 1993).

In the present paper we have investigated the effect of age and anti-ageing CR regimens (mild or severe) on the unstimulated angiogenic capacity of rat aortal. The rat aortic ring model has gained broad acceptance as an angiogenetic assay (Zhu and Nicosia, 2002). Our data show that unstimulated angiogenesis is retained by aorta explants from middle-aged rats, and is lost by aortic rings from older rats almost completely.

With regard to the effects of caloric restriction on angiogenesis, no improvement in wound repair, in reduction in wound area over tissue, and in the rate of proliferative fibroblasts and endothelial cells at the wound edge was reported by (Reed et al. 1996) in old 40\% CR mice (but beneficial effects were seen in $\mathrm{CR}$ and re-fed mice). To our knowledge, the effects of a mild antiageing CR regimen were not studied. Here we show that antiageing CR had a significant beneficial effect on unstimulated angiogenesis in the aorta model, which was quite small, however, unlike most other antiageing effects of CR (e.g. Masoro, 2002), including the effects on ET-1 expression in this paper. The effects of a mild CR on unstimulated angiogenesis were not smaller than those of a severely restricted regimen. This finding should not surprising, since very low levels of CR were shown to have a significant effect on survival, and the incidence of neoplastic lesions is known to be lower in CR than in AL rats but very similar in 10\% and 40\% CR rats (Duffy et al., 2004a). On the other hand, severity of chronic heart and kidney diseases was reduced in all CR groups with a significant CR-dependent linear trend (Duffy et al., 2004b). With regard to the effects at the cellular and molecular level, a mild CR regimen had sub maximal beneficial antiageing effects on age-changes in liver autophagy and on tissue accumulation of a biomarker of ageing like dolichol, while severe CR fully prevented the age-related impairment of both parameters (Parentini et al., 2005). 


\section{ET-1 level during ageing and caloric restriction regimen}

In order to gain insight into the molecular mechanism on endothelial cells triggered by ageing and antiageing CR, we have investigated effects on the level of expression of ET-1 under the same conditions. Recently, a decrease in the expression of ET-1 mRNA was found in the aortas of a sedentary aged group compared with the sedentary young group, and change was prevented by exercise training (Maeda et al., 2002). Our data show that the levels of ET-1 decrease during ageing, and may support the conclusions by Maeda et al. (2002). Very interesting, CR, the most effective antiageing intervention, restored the expression of ET-1 to levels detected in young animals (3.5 month old) both in middle aged and in aged rats. CR was shown to reduce several age-dependent degenerative alterations in rat aorta and an antiatherosclerotic action was suggested (Fornieri et al., 1999). To our knowledge this is the first study demonstrating an anti-aging effect of CR on ET-1 expression.

Taken together, our findings show that ageing impairs the angiogenic capacity of rat aorta and ET-1 expression with a different time-lag that CR may counteract change in part and that mild and severe CR regimens may have similar beneficial effects. Loss of endothelial function associated with advancing age may have important clinical implication for the pathogenesis of cardiovascular disease.

In conclusion, our observation that low level CR may exert a significant beneficial effect on aortic endothelium, invites to investigate on an effective mild $\mathrm{CR}$ regimen as anti-ageing intervention in spite of an intensive regimen (like EOD). 


\section{Legends to figure}

Figure 1. Panel A. The angiogenic capacity of rat aortic rings. Thoracic aorta was removed by young (3.5-months-old rats), middle (12-months-old) and aged (24-months-aged) untreated animals (AL). Bars showed the number of microvessels \pm SD counted at $8^{\text {th }}$ day in four independent rings obtained by each rat analysed (3 rats for each point).

Panel B. The angiogenic capacity of rat aorta rings isolated by 24-months-old rats untreated (AL) or treated (EOD or FW). The angiogenic response was measured as described in panel A.

Figure 2. Expression of ET-1 in aorta of 3.5- and 24-month old rats (panel A) and in animals submitted to EOD or FW regimen (panel B) by means of immunohystochemistry. 


\section{References}

Blacher, S., Devy, L., Burbridge, M.F., Roland, G., Tucker, G., Noel, A., Foidart, J.M., 2001. Improved quantification of angiogenesis in the rat aortic ring assay. Angiogenesis 4, 133-142.

Chavakis, E., Dimmeler, S., 2002. Regulation of endothelial cell survival and apoptosis during angiogenesis. Arterioscler. Thromb. Vasc. Biol. 22, 887-893.

D’Amore, P.A., Thompson, R.W., 1987. Mechanisms of angiogenesis. Annu. Rev. Physiol. 49, 453-464.

Duffy, P.H., Lewis, S.M., Mayhugh, M.A., Trotter, R.W., Latendresse, J.R., Thorn, B.T., Feuers, R.J., 2004a. The effects of different levels of dietary restriction on neoplastic pathology in the male SpragueDawley rat. Aging Clin. Exp. Res. 16, 448-456.

Duffy, P.H., Lewis, S.M., Mayhugh, M.A., Trotter, R.W., Thorn, B.T., Feuers, R.J., Turturro, A., 2004b. The effects of different levels of dietary restriction on non-neoplastic diseases in male SpragueDawley rats. Aging Clin. Exp. Res. 16, 68-78.

Edelberg, J.M., Reed, M.J., 2003. Aging and angiogenesis. Front. Biosci. 8:s1199-1209. Review.

Fornieri, C., Taparelli, F., Quaglino, D. Jr., Contri, M.B., Davidson, J.M., Algeri, S.,

Ronchetti, I.P., 1999. The effect of caloric restriction on the aortic tissue of aging rats. Connect. Tissue Res. 40, 131-143.

Harman, D., 2001. Aging: overview. Ann. NY Acad. Sci. 928, 1-21. Review.

Hoffmann, J., Haendeler, J., Aicher, A., Rossig, L., Vasa, M., Zeiher, A.M., Dimmeler, S., 2001. Aging enhances the sensitivity of endothelial cells toward apoptotic stimuli: important role of nitric oxide. Circ. Res. 89, 709-715.

Iemitsu, M., Miyauchi T., Maeda S., Tanabe T., Irukama-Tomobe Y., Goto K, Matsuda M., Yamaguchi I., 2002. Effects of aging and subsequent exercise training on gene expression of endothelin-1 in rat heart. Clinical Science 103, 152S-157S.

Lynch, C.D., Cooney, P.T., Bennett, S.A., Thornton, P.L., Khan, A.S., Ingram, R.L., Sonntag, W.E., 1999. Effects of moderate caloric restriction on cortical microvascular density and local cerebral blood flow in age rats. Neurobiol. Aging. 20, 191-200.

Maeda, S., Miyauchi, T., Iemitsu, M., Tanabe, T., Yokota, T., Goto, K., Yamaguchi, I., Matsuda, M., 2002. Effects of exercise training on expression of endothelin-1 mRNA in the aorta of aged rats. Clin. Sci. (Lond). 48, 118S-123S.

Marasciulo, F.L., Montagnani, M., Potenza, M.A., 2006. Endothelin-1: the yin and yang on vascular function. Curr. Med. Chem. 13, 1655-1665. Review.

Masoro, E.J., 2002. Caloric restriction: a key to understand and modulating aging, ed. J. Vijg, 
Amsterdam.

Mattison, J.A., Lane, M.A., Roth, G.S., Ingram, D.K., 2003. Calorie restriction in rhesus monkeys. Exp. Gerontol. 38, 35-46.

McCaffrey, T.A., Falcone, D.J., 1993. Evidence for an age-related dysfunction in the antiproliferative response to transforming growth factor-beta in vascular smooth muscle cells. Mol. Biol. Cell. 4, 315322.

Mogford, J.E., Tawil, N., Chen, A., Gies, D., Xia, Y., Mustoe, T.A., 2002. Effect of age and hypoxia on TGF beta 1 receptor expression and signal transduction in human dermal fibroblasts: impact on cell migration. J. Cell Physiol. 190, 259-265.

Mukherjee, P., Abate, L.E., Seyfried, T.N., 2004. Antiangiogenic and proapoptotic effects of dietary restriction on experimental mouse and human brain tumors. Clin. Cancer Res. 10, 5622-5629.

Nicosia, R.F., Ottinetti, A., 1990. Growth of microvessels in serum-free matrix culture of rat aorta. A quantitative assay of angiogenesis in vitro. Lab. Invest. 63, 115-122.

Nicosia, R.F., Nicosia, S.V., Smith, M., 1994. Vascular endothelial growth factor, platelet-derived growth factor, and insulin-like growth factor-1 promote rat aortic angiogenesis in vitro. Am. J. Pathol. $145,1023-1029$.

Parentini, I., Cavallini, G., Donati, A., Gori, Z., Bergamini, E., 2005. Accumulation of dolichol in older tissues satisfies the proposed criteria to be qualified a biomarker of aging. J. Gerontol. A Biol. Sci. Med. Sci. 60, 39-43.

Payne, A.M., Dodd, S.L., Leeuwenburgh, C., 2003. Life-long calorie restriction in Fischer 344 rats attenuates age-related loss in skeletal muscle-specific force and reduces extracellular space. J. Appl. Physiol. 95, 2554-2562.

Reed, M.J., Penn, P.E., Li, Y., Birnbaum, R., Vernon, R.B., Johnson, T.S., Pendergrass, W.R., Sage, E.H., Abrass, I.B., Wolf, N.S., 1996. Enhanced cell proliferation and biosynthesis mediate improved wound repair in refed, caloric-restricted mice. Mech. Ageing Dev. 89, 21-43.

Reed, M.J., Corsa, A.C., Kudravi, S.A., McCormick, R.S., Arthur, W.T., 2000. A deficit in collagenase activity contributes to impaired migration of aged microvascular endothelial cells. J. Cell. Biochem. $77,116-126$.

Reed, M.J., Ferra, N., Vernon, R., 2001. Impaired migration, integrin function, and actin cytoskeletal organization in dermal fibroblasts from a subset of aged human donors. Mech. Ageing Dev. 122, 12031220.

Rivard, A., Fabre, J.E., Silver, M., Chen, D., Murohara, T., Kearney, M., Magner, M., Asahara, T., Isner, J.M. 1999. Age-Dependent impairment of angiogenesis. Circulation 99, 111-120.

Roth, G.S., Ingram, D.K., Lane, M.A., 1999. Calorie restriction in primates: will it work and how will we know? J. Am. Geriatr. Soc. 47, 896-903. 
Thompson, H.J., McGinley, J.N., Spoelstra, N.S., Jiang, W., Zhu, Z., Wolfe, P., 2004. Effect of dietary energy restriction on vascular density during mammary carcinogenesis. Cancer Res. 64, 5643-5650.

Vasa, M., Breitschopf, K., Zeiher, A.M., Dimmeler, S., 2000. Nitric oxide activates telomerase and delays endothelial cell senescence. Circ. Res. 87, 540-542.

Williams, M., 1998. Approach to managing the ederly patient, in: Hazzard, W., Blass, H., Ettinger, W., Halter \& J. Ouslander., Mc Graw-Hill. (Eds.), Principles of Geriatric Medicine and Gerontology. EPublishing Inc., New York, pp. 249-253.

Yanagisawa, M., Kurihara, H., Kimura, S., Tomobe, Y., Kobayashi, M., Mitsui, Y., Yazaki, Y., Goto, K., Masaki, T., 1988. A novel potent vasoconstrictor peptide produced by vascular endothelial cells. Nature 332, 411-415.

Zhu, W.H., Nicosia, R.F., 2002. The thin prep rat aortic ring assay: a modified method for the characterization of angiogenesis in whole mounts. Angiogenesis 5, 81-86. 
Table 1 - Body weight, food consumption and survival data.

\begin{tabular}{|c|c|c|c|}
\hline & AL & FW & EOD \\
\hline Body weight $(\mathbf{g})$ & & & $451 \pm 32.3^{*}$ \\
\hline 6 months & $529 \pm 37.4$ & $514 \pm 37.0$ & $497 \pm 42.5^{*}$ \\
\hline 12 months & $627 \pm 48.4$ & $599 \pm 48.2$ & $507 \pm 47.7^{*}$ \\
\hline 18 months & $673 \pm 45.3$ & $644 \pm 38.9$ & $508 \pm 58.4^{*}$ \\
\hline 24 months & $633 \pm 58.4$ & $621 \pm 49.6$ & $16.8 \pm 0.30^{*}$ \\
\hline Food intake (g/day) & & & $17.6 \pm 0.48^{*}$ \\
\hline 6 months & $21.6 \pm 0.73$ & $20.9 \pm 1.28$ & $16.5 \pm 0.45^{*}$ \\
\hline 12 months & $23.6 \pm 0.54$ & $21.4 \pm 0.84$ & $16.5 \pm 0.94^{*}$ \\
\hline 18 months & $24.2 \pm 1.51$ & $21.1 \pm 0.64$ & $100 \%$ \\
\hline 24 months & $22.3 \pm 1.18$ & $19.4 \pm 0.49 *$ & $100 \%$ \\
\hline Percent survival & & & $95 \%$ \\
\hline 6 months & $100 \%$ & $100 \%$ & $95 \%$ \\
\hline 12 months & $100 \%$ & $100 \%$ & $95 \%$ \\
\hline 18 months & $90 \%$ & $78 \%$ & \\
\hline 24 months & $60 \%$ & & \\
\hline
\end{tabular}

Body weight and food intake: values represent the mean \pm SD (four rats for each point); ${ }^{*}<<0.05$ with respect to AL group.

Survival was determined analysing four rats for each point. 
Table 3. Levels of ET-1 mRNA in the aorta 3.5, 12 and 24 month old rats and in immunohistochemistry to EOD or FW regimen.

$\mathrm{AL}$

$0.90 \pm 0.04$

3.5 month old

12 month old

24 month old
$0.65 \pm 0.03$

$0.53 \pm 0.02$
EOD

FW

The values are the ratio between the means \pm S.D. of densitometric value of ET- 1 with respect to the densitometric value of beta actin (three independent rats, two samples for each rat). 

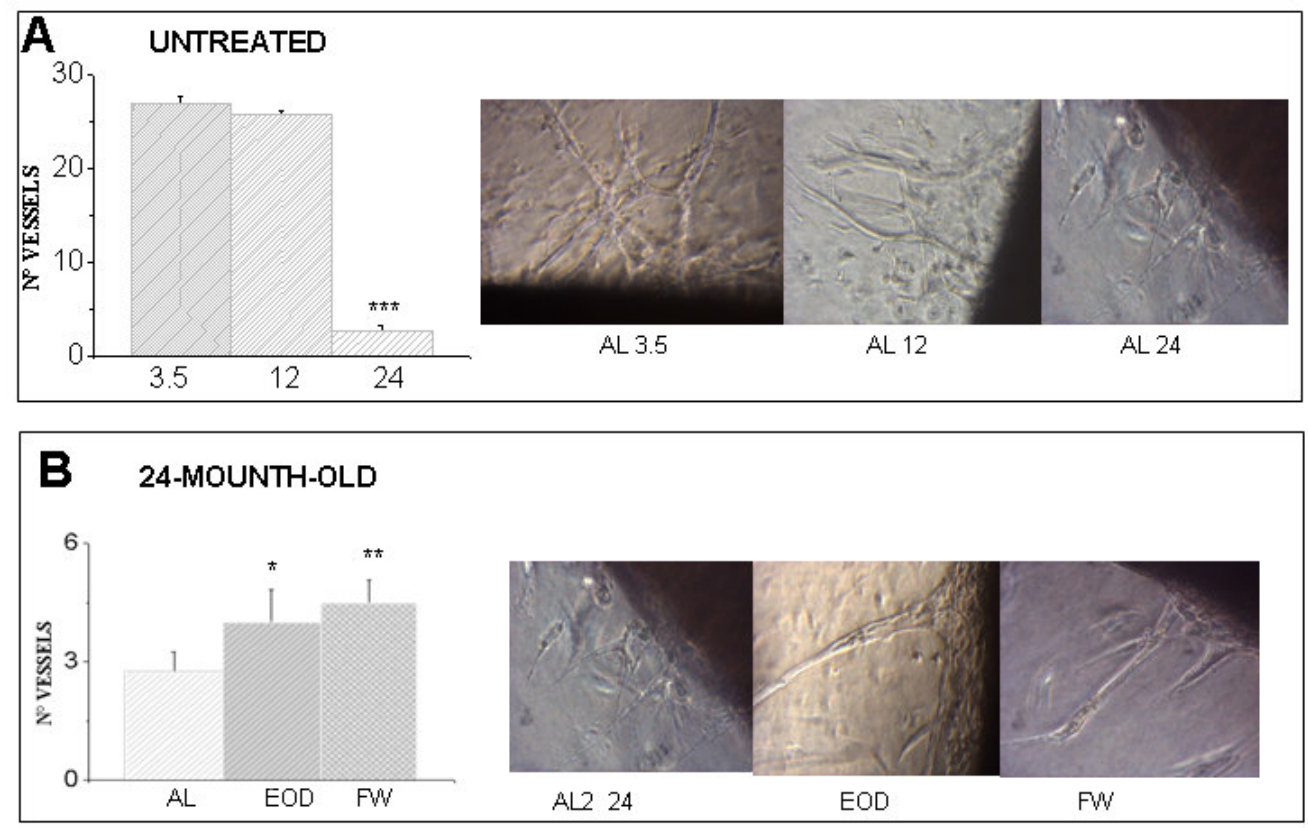

Facchetti et al.

Figure 1 
A
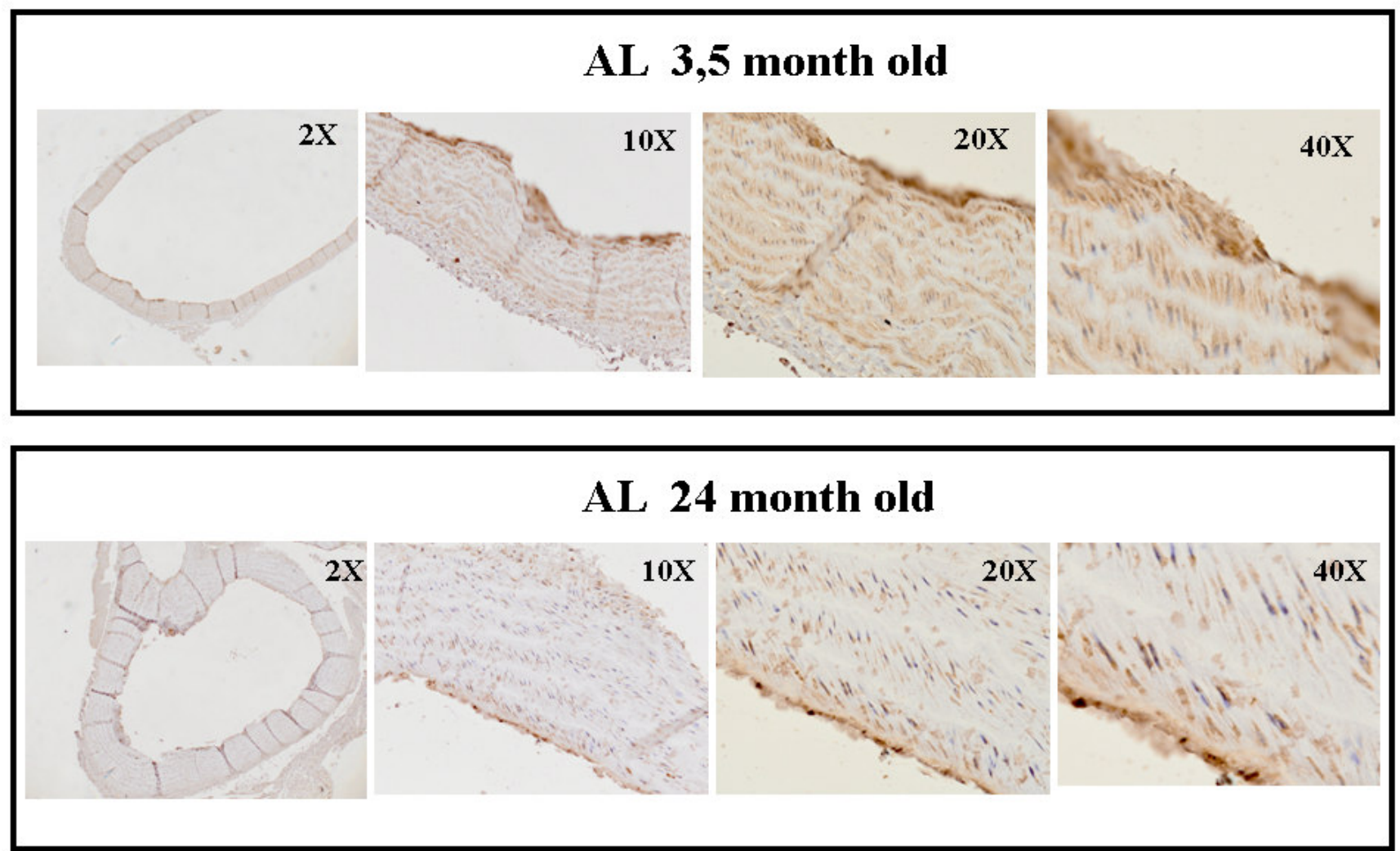

Figure 2 Facchetti et al. Panel A 
Fig. 2, Facchetti et al Panel B

AL 24 month old

B
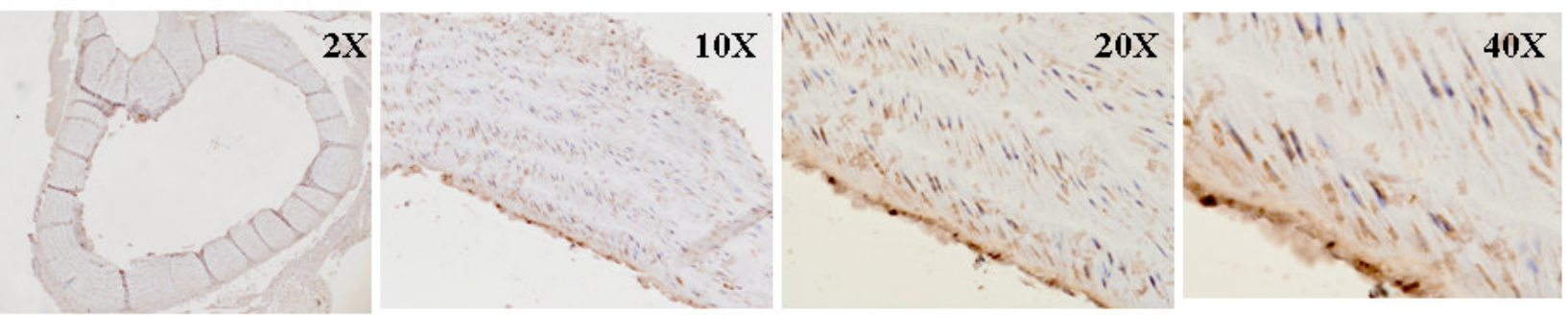

FW 24 month old

$2 \mathrm{X}$
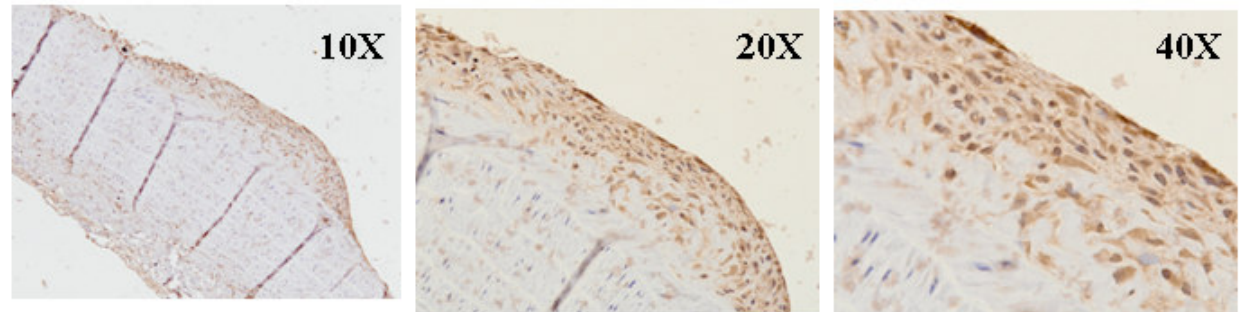

EOD 24 month old

$2 \mathrm{X}$
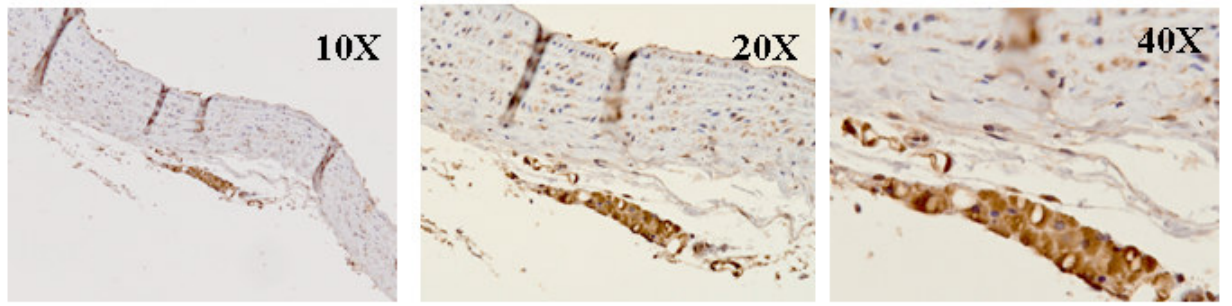